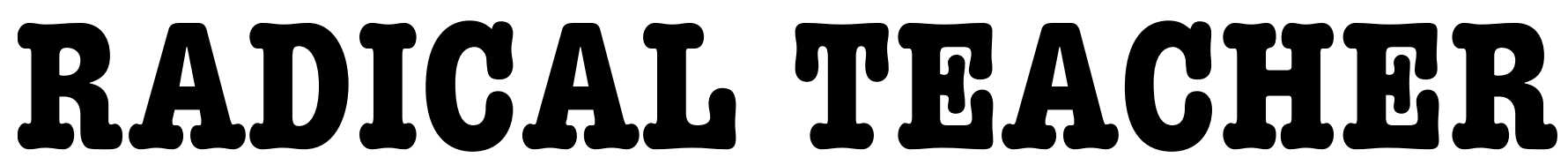

A SOCIALIST, FEMINIST, AND ANTI-RACIST JOURNAL ON THE THEORY AND PRACTICE OF TEACHING

\title{
Introduction: \\ Teaching Across Borders
}

by Linda Dittmar and Frinde Maher

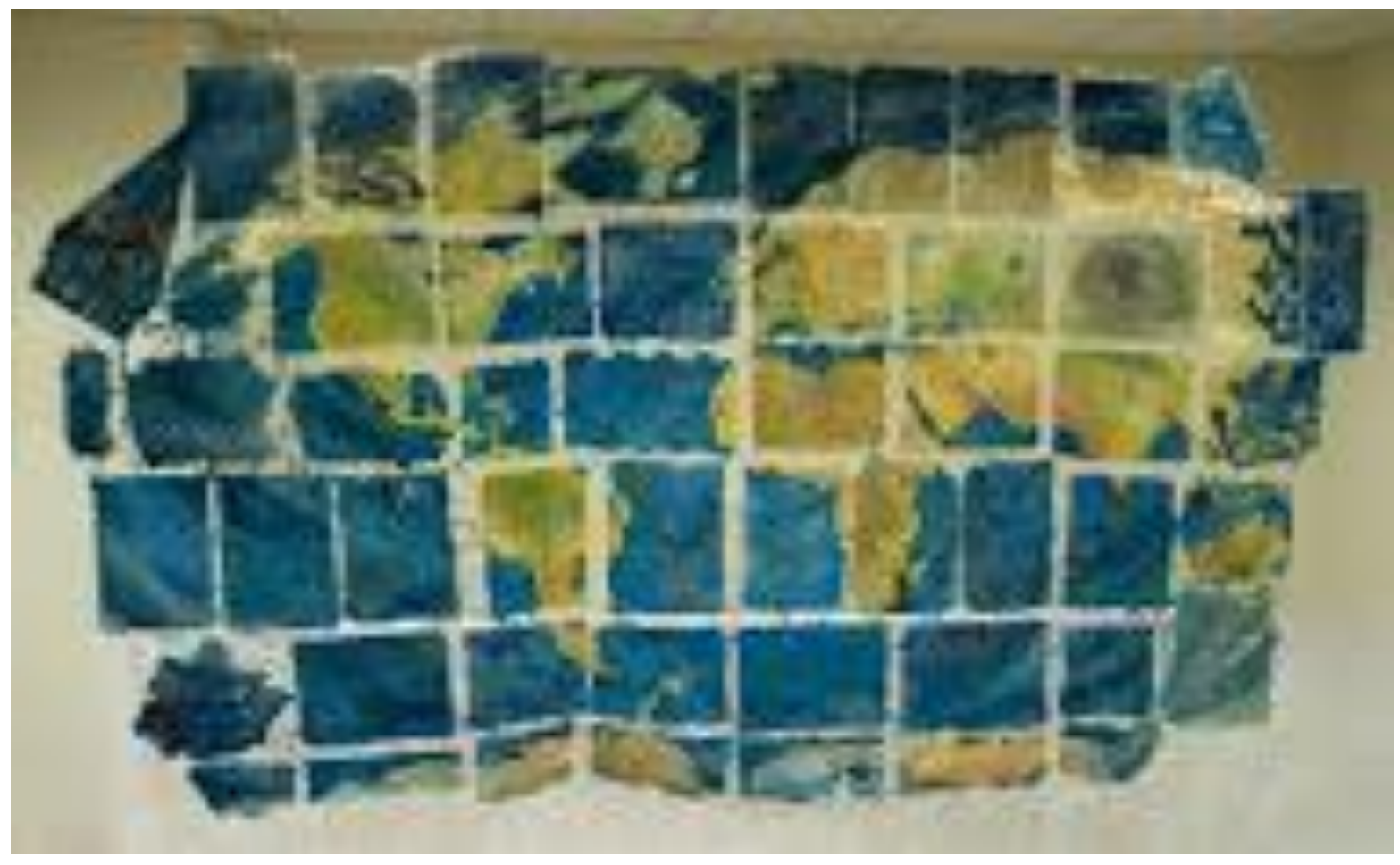

ONE WORLD MANY PAPERS COURTESY OF JANE INGRAM ALLEN 
$M$ ost of what we publish in Radical Teacher concerns teaching in the United States and speaks to the working lives of most of our readers and their students. However, articles about teaching in other countries have also occasionally appeared in our pages. These included pieces on teaching in Brazil, Kurdistan, Palestine, Israel, Mexico, the Democratic Republic of Congo, and more. These were all unsolicited submissions that reached us sporadically and got published over time. Even Radical Teacher's two clusters on "Globalism," one on "Post-colonialism," another on "Immigration," and two more on "Teaching in a Time of War," for all their geo-political and trans-national implications, did not feature centrally the challenges of teaching outside of one's familiar borders.

And yet several Board members and many other radical educators have taught in other countries over time, often in politically charged contexts of conflict and rapid social transformations. Of course the motives for these journeys always include a desire to both learn from and contribute to the countries that have hosted us. But we have other goals as well. Much of the information Americans hear at home about "us" and the rest of the world puts the United States at the epicenter of all important global anxieties and events. As internationalists, those of us who were born and brought up here seek to see both the United States from other vantage points and to see other societies and their problems from the inside out. We want to learn from progressive teachers and others about their concerns and their struggles, the local ones as well as the ones they see beyond their borders. We want to get outside the American bubble.

\section{Several Board members and many other radical educators have taught in other countries over time, often in politically charged contexts of conflict and rapid social transformations. Of course the motives for these journeys always include a desire to both learn from and contribute to the countries that have hosted us.}

Thus there is a need for multiple discussions around the challenges of teaching abroad. Beyond the far-flung teaching and lecturing sponsored by U.S. agencies such as the State Department's Fulbright Program, there are assorted other opportunities, including governmentsponsored invitations by foreign institutions and the mushrooming of American universities' overseas extensions meant to serve local populations, perhaps most famously those in the Gulf States.

In tandem with this exporting of American (and Western) education is an opposite flow of faculty and teachers migrating transnationally into the United States and elsewhere. Unlike many Americans' short term "tours of duty" abroad, this migration is brokered individually, case by case, and tends to be less visible to American hosts. It also tends to be longer term, sometimes permanent. As such, it involves a somewhat different set of bureaucratic, professional, emotional, and political commitments than the semester or program or year abroad that Americans undertake. Here too newcomers must learn to navigate the differences between "Us" and "Them," though this time with the "Them" being their American university counterparts.

At issue is all that remains
unspoken regarding our presence in
that classroom in the first place:
Why am I here? Whose interests
are being served by my teaching?
What use is this teaching to these
students and/or to my host
country? And conversely, in what
ways is my teaching useless,
disrespectful, and perhaps even
deleterious from the host country's
and/or students' point of view?

Either way, teaching across borders is a sensitive matter. Beyond differences in language or curricula and other practicalities, it involves relations of hosts and guests, empathy and criticism, speaking up and keeping silent, coercion and freedom. It is hard to write candidly about this topic under all circumstances. Teaching outside one's own country is teaching outside one's comfort zone. Being an outsider throws the politics as well as content of teaching into high relief. Differences in assumptions and possibilities get accentuated and the political implications of what one does-or avoids doing-in the classroom rise to the surface. This is most obviously the case when a westerner teaches in less privileged contexts-in Myanmar, Pakistan, South Africa or India for example (all included in this cluster), but not only there. It could be France, Spain, Scotland, or Denmark, too.

At issue are not just the challenges of teaching in the midst of cultural and/or linguistic differences. At issue is all that remains unspoken regarding our presence in that classroom in the first place: Why am I here? Whose interests are being served by my teaching? What use is this teaching to these students and/or to my host country? And conversely, in what ways is my teaching useless, disrespectful, and perhaps even deleterious from the host country's and/or students' point of view? And finally, what is so "radical" about such teaching even if it occurs in countries ravaged by wars, marked by colonialism, suffering poverty, and scarred by human rights abuses?

The difficulty of these questions haunts this cluster of essays. When we Americans teach abroad we confront the power relations between ourselves (willy-nilly representing the American imperium) and "them" (country after country where we perform this representation), including the difficulty of what can and can't be said in our articles. It is easy, at least relatively, to critique our own institutions and conditions of learning, as we do in Radical Teacher even as we introduce alternatives; we do so at "home," on familiar 
ground. Writing about such teaching from an outsider's perspective has one step on thin ice. One's best intentions may include unconscious disrespect and recoil, or they may be seen as such, as happened to one visiting American faculty who asked a Nepali Ph.D. candidate why he was researching Saul Bellow only to be told, "Why are you asking? Do you think we are not good enough to work on him?" Similar instances are found in the articles gathered here.

Radical teachers, and others too,
may also be faced with their host
countries' institutional pressures to
watch what they say politically,
conform to local norms and
customs, and be careful about
getting ensnared in institutional
struggles ranging from dress code
to curricular priorities, from
avoiding religious discussions to
debates about "standards."

When the contact is across disenfranchisements, the hegemonic power of the visiting outsider can be overwhelming, and all the more so when the outsider is American. This is not a matter of thin skin, whatever its color. The realities of U.S. imperialism, racism, and condescension are liable to taint any innocent exchange.

Issues of pedagogy also crop up across borders, including situations where Americans used to a collectivist approach to teaching "critical thinking" find themselves in classroom settings where traditional lectures are the predominant pedagogical mode and teachers are considered the ultimate and unquestioned authority. What happens when an American professor used to a more open-ended, skeptical way of teaching, tries to have students ask questions and even critique the teacher's authority-in China, for example, or Myanmar, or even France-only to find the students, quite appropriately for their norms, silent? "We want to know what you have to teach us," they might think. "You are here to teach us about our subject matter. Why have you come all this way just to ask us questions?" Radical teachers in particular may have a hard time shifting from collaborative teaching and learning to a more authoritarian "banking" model so often critiqued on these pages.

Radical teachers, and others too, may also be faced with their host countries' institutional pressures to watch what they say politically, conform to local norms and customs, and be careful about getting ensnared in institutional struggles ranging from dress code to curricular priorities, from avoiding religious discussions to debates about "standards." How does one respond to a colleague beleaguered by the emergence of "redundant" Women's Studies courses-"Women's Studies is not a discipline!"-or to the concern that GLBT's are "taking over" academia? Of course these are crossroads we face at home too, except that, away from home, one's visibility is magnified and the need to be accountable to one's sponsors is greater, be it the U.S. grant that funds this teaching or the local institution that invites it.

In their various ways, the articles collected here all concern the tensions of the teacher's outsider position in countries where teaching is fissured and split between the severe imperatives of defining, shaping, or discovering and re-discovering their own cultural, political, and economic identities and, at the same time, doing so in conversation with an outside world. That conversation may feel at times like a catching up, but at times it may also feel like a pitched debate. Does one aspire to become "a world class university," or locate and disseminate aspects of indigenous culture hitherto ignored and demeaned by colonialism?

In many ways the situation of being a "radical teacher" abroad, or being a "radical teacher" from abroad teaching in the United States, makes such issues particularly visible. While these issues undergird all our efforts at teaching for social justice and democracy, we don't always notice them as sharply in our home settings. Investigating the history of racism, exposing the dynamics of class exploitation and income inequality, using literature to explore the lives of women and girls across the world-we teach such topics with relative freedom in our own classrooms and our own home institutions, even if under conditions of increasing marginality, institutional indifference, and declining job security. One way of thinking about the questions raised by the articles collected in this issue is to mine them for a deeper awareness of our own situations at home as well.

The articles gathered in this cluster represent teaching and working situations from a variety of places: Israel, India, Pakistan, South Africa and Myanmar, as well as one piece by a sociologist who teaches in the United States but was born and raised in India. The one set in South Africa focuses on educational consulting but raises many of the same issues as the others. Though many of the issues they explore overlap on ones familiar to all of us, they take on new dimensions with the locations and dislocations of teaching across borders.

The articles gathered in this cluster represent teaching and working situations from a variety of places: Israel, India, Pakistan, South Africa and Myanmar, as well as one piece by a sociologist who teaches in the United States but was born and raised in India. 


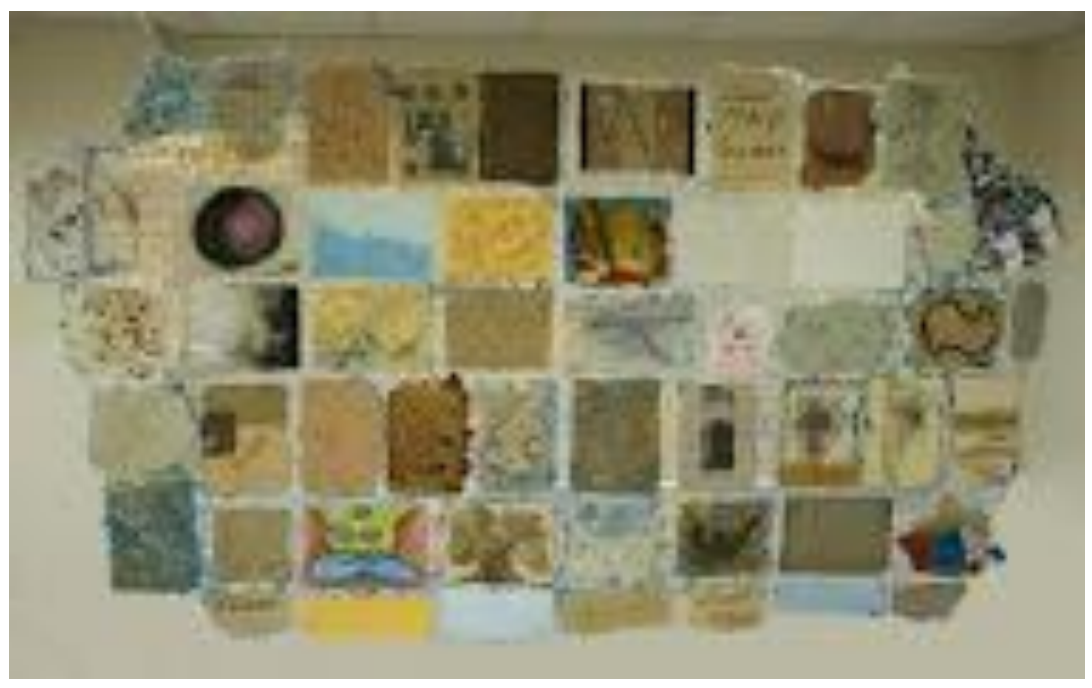

COURTESY OF JANE INGRAM ALLEN

\section{$((c))$ EY-NC-No}

ULLS D-Sonte
This work is licensed under a Creative Commons Attribution-Noncommercial-No Derivative Works 3.0 United States License.

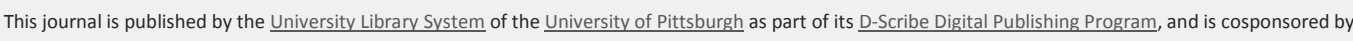
the University of Pittsburgh Press.

\section{RADICAL TEACHER}

http://radicalteacher.library. pitt.edu
No. 101 (Winter 2015)

DOI $10.5195 /$ rt.2015.195 